\title{
Parasocial Relationships \\ in the Modern Russian Society: \\ Sociological Analysis \\ in the Context of Regional Research
}

\author{
Aleksey S. Novikov* \\ Siberian Federal University \\ 79 Svobodny, Krasnoyarsk, 660041, Russia
}

Received 18.03.2015, received in revised form 19.05.2015, accepted 12.07.2015

The research paper considers the problem of studying parasocial relationships in the modern Russian society. In particular, the importance of such an analysis in the context of sociological, philosophical and psychological studies of the region population it postulated. Parasocial relationships are an important socio-cultural factor and their study can significantly enrich the idea of such socio-cultural phenomena as identity of the region residents. The research paper substantiates the necessity of an interdisciplinary approach to the subject of parasocial relationships and reveals the specific character of sociological focus of the phenomenon consideration.

Keywords: parasocial relationships, social exchange, atomization of society, sociology of emotions, regional identity.

The study is carried out on the basis of researches, done with financial support from RHSF, project № 13-03-00379a "Dynamics of Sociocultural Processes in East Siberian Region within the Context of Contemporary Modernization of Russia (Based on Materials of Sociological Researches in Krasnoyarsk Krai)".

DOI: $10.17516 / 1997-1370-2015-8-11-2554-2560$

Research area: sociology.

\section{Problem Statement}

The concept of parasocial relationships is quite new for Russian social sciences and humanities. The concept of parasocial relationships as special relationships established between the viewer and the hero of mass media message was introduced by Horton and Wohl in "Mass Communication and Para-Social Interaction" (Horton \& Wohl).
According to David Giles in his review article "Parasocial Interaction: A Review of the Literature and a Model for Future Research» (Giles, 2002), it would be natural to expect interest to the subject of parasocial relationships on the part of psychologists, but until at least 1986 there were works within the framework of psychological subjectness of works that reveal the essence of parasocial relationships.

(c) Siberian Federal University. All rights reserved

* Corresponding author E-mail address: asnovikov@gmail.com 
This does not mean, however, that psychological subjectnessinthestudy of parasocial relationships was completely excluded. In modern psychology parasocial relationships are widely studied, but they are understood as a specific social phenomenon that also naturally provides the possibilities of sociological analysis.

Within the framework of this research paper, a brief methodological reflection connected with the analysis of the concept of parasocial relationships would be justified. This methodological reflection will have the purpose to establish characteristic attributes of the theory of parasocial relationships, typical of psychology and sociology.

Let us begin with the fact that parasocial relationships in psychology are interpreted not as, basically, the relationships of social exchange, but as a special type of social interaction, deprived of this component.

In particular, in the work by E. Perse and R. Rubin «Attribution in Social and Parasocial Relationships» (Perse \& Rubin, 1989) attributive processes that traditionally are a field of interdisciplinary research which are in the field of interest of both social psychology and sociology are studied.

The idea of social relations, as well as relations not based on exchange, deserves special attention, which can demonstrate not only a specific sociological approach, but the novelty of methodological foundations in considering parasocial relationships within the framework of sociological subjectness.

According to D. Hopkins in her work "Theorizing Emotions: Sociological Explorations and Applications" (Hopkins, 2009, p. 317), when studying parasocial relationships emotions, as a factor of social reality, play the key role. Rationalizing methodological foundations of this approach, Hopkins appeals to such classics of sociology as
Simmel and Durkheim. She also refers to social structuralism and post-structuralism. Thus, we can talk about quite an established tradition of studying relationships and emotions associated with them in sociology.

All this allows us to say that parasocial relationships can be the subject of sociology to the same extent as other classical psychological concepts such as emotions and feelings. In other words, the subject of sociology is not so much the characteristic properties of experiencing emotions as social conditions that make experiencing emotions possible and set its context.

Sociological aspect of emotional processes is widely studied in Russian sociology. A good example of this approach is works of scientific school of V. Nemirovsky, in which the conception of life-purpose orientations and emotional orientation of person (see, in particular, the following works: (Nemirovsky, 1994; 2001; Koptseva \& Seredkina, 2013; Nemirovsky, 2006; 2008; 2009; Nemirovsky \& Nemirovskaya, 2011) is actively developing.

The importance of the subject of parasocial relationships for a number of areas related not only to sociology, but to the social philosophy and ethnography as well should be also noted separately.

\section{Major Results}

In the number of works by sociologists, psychologists, and philosophers of the late $19^{\text {th }}-$ early $20^{\text {th }}$ centuries, a completely different type of relationships, based on emotional experiences is mentioned. S. Freud, in particular, in "Group Psychology and the Analysis of the Ego", talking about the nature of the relationships that define group, supports this conception. These relations for Freud are not social in the classical sense, they are not based on exchange. Relationships that form the basis of groups and mass communities (crowd, audience in G. Tarde' understanding) 
are generally unilateral in relation to an external object or idea.

This necessarily leads us to the concept of identity. Correlation of the concepts of identity and the process of social exchange can be the subject of a separate research paper. But it can be stated that it is parasocial relationships that form a basis in the process of group and, generally, ethnic identity formation. The subjects of ethnic identity started to be widely discussed in scientific literature in the second half of the $20^{\text {th }}$ century, but the roots of concept go back to the classical works of G. Le Bon, G. Tarde and especially to the "Problems of Social Psychology" by Wilhelm Wundt, who is also the founder of the classic scientific psychology.

The methodology of studying the issues of ethnic identity emphasizes interdisciplinary nature of the phenomena, which naturally includes the necessity of not only psychological but also sociological, as well as social and philosophical approaches.

That is why the problematics of ethnic identity is studied within the framework of social and philosophical subjectness. Ethnic identity in this case is represented as a rather complex phenomenon, which finds manifestation in different representations of not only spiritual but also material culture.

Such a methodological principle is quite widely spread and successfully implemented in a number of works of both foreign and Russian researchers. In particular, one of its prominent representatives is N.P. Koptseva, and this approach was implemented in the monograph "Construction of Positive Ethnic Identity in a Multicultural System" (Koptseva \& Seredkina, 2013; Koptseva, 2011).

Summarizing the above mentioned, it can be stated that parasocial relationships are currently the subject of interdisciplinary research that are in the field of interests of the three humanities: sociology, communication theory and psychology. Communication structures and channels where parasocial relationships are formed are in sphere of communication theory interests. The sphere of psychology interests is those psychological conditions that characterize the experience of parasocial relationships. But within sociological subjectness those social conditions and circumstances that lead to parasocial relationships formation are of great interest.

Next we will consider those social conditions that can lead to parasocial relationships emergence and their development.

In general, beginning with the first studies on the subject of parasocial relationships, it is possible to detect two factors mentioned by a number of researchers. Firstly, it is increasing media consumption. Secondly, it is emotional detachment that accompanies media products consumption.

Emotional detachment is spread in society, it affects social relations and it is the reason why it becomes the subject of analysis of sociology and social philosophy. Such tendencies as breaking up social relations based on exchange are widely analyzed.

It is the principle of social exchange that defines social relations, which were the subject of sociological analysis. Therefore, variations of scientific approaches and methodological transformation, which we have seen in the recent decades is only a consequence of the object and dynamics of social relationships transformation as well as modification of their very essence.

Dissociation of social exchange leads to the formation of a new type of society. In the conceptual framework of social conflicts theory, in particular, such communities are characterized as those implementing competitive strategies, and the widespread use of such strategies is counterproductive for all the community members. 
The structure of social actors changes as well. It is possible to say that communities of any types and kinds become less stable; they are easily organized and just as easily break up (Hindess, 2015).

All these circumstances lead to an increase in the distance between social action and feedback. In some cases, for example, if we talk about online communities, the feedback is almost completely lost.

A special type of social actions is formed. The behaviour itself in such actions is distanced from its effect and feedback, what generates social passivity. Such passivity most clearly manifests itself, for example, in the results of studies of the contemporary Russian voters' political behavior.

The phenomenon of decrease in election voters turnout at all the elections without exception is widely known, that allows talking about citizens' unwillingness to participate in the political process. This phenomenon is also found in the results of numerous highquality researches. A large number of works on this subject is qualitatively summarized and studied, for example, in the doctoral thesis by T.V. Plotnikova "Political Behavior in Russia: Social and Philosophical Analysis" (Plotnikova, 2009).

Social acts transformation is naturally reflected on the sphere social values. This transformation process is studied within the framework of antroposociocultural approach by N.I. Lapin and the basic provisions in this regard are outlined in a number of studies (Lapin, 2010; 2009; Nemirovsky, 2001; Nemirovsky \& Nemirovskaya, 2014).

Thus, in modern Russian society the gap between different types of social behavior and its results is increasing. The awareness of this gap leads to the fact that social actors in some cases also refrain from behaviour, and thus from the responsibility for it. The key here is the fact that behavior is not embarked because it does not lead, according to the actor, to any tangible results. And the result itself is described by social subject exclusively from the position of short-term and observed directly.

In general, this allows us to talk about the phenomenon of social infantilism, which can be characterized in the following way: social infantilism, primarily, is reduced to avoidance (or transfer) of responsibility. E. Fromm (Fromm, 2006; 2015), in particular, followed this understanding of infantilism.

It should be said that such an understanding of social infantilism is peculiar to the Frankfurt School in general. The thinkers of the Frankfurt School also talked about a number of social conditions connected with emergence and development of social infantilism. In the infantile society the processes of atomization and massovisation are increasing, social actors themselves are separated from the results of their behavior, and, furthermore, such distancing becomes widespread and sets, in such a way, a kind of social norm.

\section{Resume}

The factors, outlined in this paper are directly supported by the results of the regional empirical studies conducted in Krasnoyarsk Krai with our participation under the leadership of V.G. Nemirovsky. According to the data obtained, despite gradual overcoming of the processes of atomization of regional society, they are very important for the region development. On the whole, decomposition of social ties among its citizens is preserved, regional and all-Russian identity of its population remains low. Only about a quarter of the residents self-identify themselves with the population of Russia. Personal distrust of the region population is quite high, external locus of control prevails among a large proportion of the respondents (Koptseva \& Seredkina, 2013). 
Thus, it is possible to talk about the following theoretical and methodological implications that can be formulated after analyzing parasocial relationships theory:

1. Parasocial relationships are the type of relationships that require not only special psychological description, but sociological, as wellas socio-philosophical interpretation.

2. Parasocial relationships extension leads to social actors instability and responsibility diffusion, associated with the various types of social behavior.
3. Substitution of social relations with parasocial leads to the spread of social infantilism, which is a direct consequence of the new structure of relationships.

4. Social infantilism, in turn, is connected with the tendencies of massovisation and atomization of society.

5. The outlined conception, along with antroposociocultural approach by N.I. Lapin, can be effectively used when studying the processes of sociocultural modernization of the regions.

\section{References}

Fromm, E. Anatomia chelovecheskoi destruktivnosti [Anatomy of Human Disruptiveness], Moscow, AST, 2006, 624 p.

Fromm, E. Begstvo ot Svobody [Escape from Freedom], Moscow, AST, 2015, 288 p.

Giles, D. C. (2002) Parasocial Interaction: A Review of the Literature and a Model for Future Research. Mediapsychology, 4, 279-305.

Hindess, B. Rationality and Social Theory. London, Routledge, 2015.

Hopkins, D. Theorizing Emotions: Sociological Explorations and Applications, 2009.

Horton, D. \& Wohl, R. R., Mass Communication and Para-Social Interaction, Psychiatry, pp. 19, 215-229.

Koptseva, N.P. \& Seredkina, N.N. Konstruirovanie pozitivnoi etnicheskoi . identichnosti v policul'turnoi sisteme [Construction of Positive Ethnic Identity in a Multicultural System], Krasnoyarsk, SibFU, 2013, 184 p.

Koptseva, N.P. \& Il'beikina, M.I. Tsivilizatsionnaia napravlennost' naseleniia ob"edinennogo Krasnoiarskogo kraia: zhiteli goroda Krasnoyarska v vozraste ot 15 do 60 let [Civilizational Orientation of the Population of the United Krasnoyarsk Krai: Dwellers of the City of Krasnoyarsk Aged From 15 to 60]. Expert Club "Committee of Development". 05.06.2011.

Lapin, N.I. (2011). Sotsiocul'turnye factory rossiiskoi stagnatsii i modernizatsii [Sociocultural Factors of Russian Stagnation and Modernization]. Sociocultural Studies, 9, 3-17.

Lapin, N.I. (2010). Funktsional'no-orientiruiushchie klastery basovykh tsennostei naseleniia Rossii i ee regionov [Functionally-Orienting Clusters of the Basic Values of the Population of Russia and its Regions]. Sociocultural Studies, 1, 28-36.

Lapin, N.I. (2009). Tsennosti "sokhranenie - otkrytost' izmeneniiam" i setevye innovatsionnye instituty [Values "Preservation - Openness to Changes" and Networking Innovative Institutions]. Social Sciences and Modernity, 5, 37-51.

Nemirovsky, V.G. \& Sokolova E.V. Structura $i$ dinamika smyslozhiznennykh orintatsii studencheskoi molodezhi: 1988-2004 gg. Postneoklassicheskii podkhod [Structure and Dynamics of 
Life-Purpose Orientations of Student Youth: 1988-2004. Post-Neoclassical Approach]. Krasnoyarsk, KrasSU PPD, 2006, 161 p.

Nemirovsky, V.G. (2006). Massovoe soznanie i bessoznatel'noe kak ob“ekt postneoklassicheskoi sotsiologii [Mass Consciousness and Unconsciousness as an Object of Post-neoclassical Sociology]. Sociological Studies, 2, 13-19.

Nemirovsky, V.G. Rossiiskii krizis v zerkale postneoklassicheskoi sotsiologii [Russian Crisis in the Mirror of Post-neoclassical Sociology]. Moscow, Knizhnyi Dom “Librocom”, 2009. 200 p.

Nemirovsky, V.G. (1994). Sovremennaia sotsiologiia i rossiiskie kul'turnye traditsii [Modern Sociology and Russian Cultural Traditions]. Sociological Studies, 3, 23-29.

Nemirovsky, V.G. Universumnaia diagnostika rossiiskogo obshchestva [Universum Diagnostics of Russian Society]. Krasnoyarsk, 2001, 176 p.

Nemirovsky, V.G.\&Nevirko,D.D. Sotsiologiiacheloveka: otklassicheskikhkpostneoklassicheskim podkhodam [The Sociology of Man: From Classic to Post-neoclassical Approaches]. SibLI PPD, 2008, $396 \mathrm{p}$.

Nemirovsky, V.G. \& Nemirovskaya, A.V. Sotsial'naia struktura i sotsial'nyi capital naseleniia [Social Structure and Social Capital of the Population of Krasnoyarsk Krai]. Krasnoyarsk, SibFU, 2011, $158 \mathrm{p}$.

Nemirovsky, V.G. \& Nemirovskaya, A.V. Sotsiokul'turnye protsessy v Sibirskom regione (Krasnoyarskii krai v 2010 - 2014 gg.) [Sociocultural Processes in Siberian region (Krasnoyarsk Krai in 2010 - 2014)]. Krasnoyarsk, SibFU, 2014, 244 p.

Perse, E. M. \& Rubin, R. B. (1989). Attribution in Social and Parasocial Relationships. Communication Research, 16(1), 59-77.

Plotnikova T.V. Poloticheskoe povedenie v Rossii: Sotsial'no-filisofskii analiz [Political Behavior in Russia: Social and Philosophical Analysis], Dissertation for the Degree of Doctor of Philosophical Sciences, Rostov-on Don, 2009. 


\title{
Парасоциальные отношения
}

\section{в современном российском обществе: \\ социологический анализ}

\section{в контексте региональных исследований}

\author{
А.С. Новиков \\ Сибирский федеральный университет \\ Россия, 660041, Красноярск, пр. Свободньй, 79
}

В статье рассмотрена проблема изучения парасоциальных отношений в современном российском обществе. В частности, постулируется значимость такого анализа 6 контексте сочиологических, философских и психологических исследований населения региона. Парасочиальные отношения являются важным социокультурным фактором, а их исследования могут существенно обогатить представление о таком социокультурном феномене, как идентичность жителей региона. В статье обоснована необходимость междисциилинарного подхода к тематике парасоциальных отношений, а также раскрыта специифика социологического фокуса рассмотрения данного феномена.

Ключевые слова: парасоциальные отночения, сочиильный обмен, атомизация общества, сочүиология эмоций, региональная идентичность.

Работа выполнена на основе исследований, проведённых при финансовой поддержке РГНФ, проект № 13-03-00379а «Динамика социокультурных прочессов в Восточно-Сибирском регионе в контексте современной модернизации России (на материалах социологических исследований в Красноярском крае)».

Научная специиальность: 22.00.00 - социиологические науки. 